\title{
The Historical Evaluation of Modernism Design
}

\author{
Weiwei Shao \\ Doctoral Students, Academy of Art, Soochow University, P.R. China \\ Associate Professor, Shandong University of Arts
}

Keywords: modernist design; history; evaluation

\begin{abstract}
The concept and behavior of modernism design are full of contradictions, which mean that the later generations have different opinions on their evaluation. The development of today's design has long been inseparable from the foreshadowing of modernist design. Restoring and defining its historical appearance has become the only way for modern design researchers.
\end{abstract}

\section{Introduction}

From Nicholas Pevsner (Nikolaus Pevsner), Sigfried Giedion (Sigfried Giedion), Reyner Banham, Tim Benton (Tim Benton)... A series of design researchers have taken part in one of the greatest trends in the history of design - the summary and writing of modernist design, because this movement is the beginning of modern design, which has completely changed the life of each of us.

Today, we have a historical position on modernism, and we are often amazed by its strong sense of ideology, the original avant-garde reaction to the background of the machine age, the social democracy with revolutionary colors, the test of more than half a century, and the embodiment of the utopian Utopian design of modernism, especially in this sense. When it comes to solving the "human centered" ideal in the urban and social environment, the design critic can no longer tolerate his fantasies. In fact, the "pure" style of modernism, like other design patterns that it criticizes, will appear to be ideal in the light of the superficial symbol, which is more symbolic than practical. Purity is not so explicit, concealment and self - centrality are equally buried, and the masses have not imagined the modernist elites who like the ivory tower. But in such a situation, modernist classic architecture stands all over the world, and the outstanding products of modernism are collected in major museums. Looking back today, we are the followers of the road of modernism. Reinforced concrete has penetrated into every inch of our living space. Abstract vision is everywhere. To deny modernism thoroughly, it is as difficult as discarding our own genealogy.

When we look back on the history of modernism design, we think that we have been standing at the intersection of the traditional paradigm and the mechanical technology, and figured out the contradictions in the times and the social background. We should not only satisfy the public, highlight the national strength, but also have the elite to lead and shape the aesthetic; it is not only to satisfy the production but also the business. At the time of success, who has the heart to rebuke the modernist as a simple and indifferent form maker? Who can not understand the social responsibility of modernists? Modernism design is a movement of style and concept from theory to practice. To be fair, modernist design is undoubtedly the most influential design trend in the twentieth Century. Therefore, modernism design, which is closely related to today's public life as 
the industrial revolution, is not as simple as some critics think. Modernism is a complex and pluralistic phenomenon, which shows different forms and ideas in different periods of modernism. The curve of the "new art" movement is parallel to the linear fashion of the The Group of Four in Glasgow; and Peter Behrens (Peter Behrens) is busy with the functional owners of AEG company. Henry van der Wilde (Henry Van de Velde) is conducting his design education exploration while Gerrard Santos (Gerard Sandoz) in the imitation of mechanical geometric patterns and indulged in a hard decorative wind, Marianne Brandt (Marianne Brandt) put her rational Utopian test on the metal teapot. Even in the development of Bauhaus, traces of irrationalism can be found. At least, before modernism was developed into an internationalist style, the opportunities and challenges faced by him were coexisting, and the strength of modernism was shown at this time. He was able to make him treat other families, from the arts and crafts movement, Sullivan, the new art movement, the four men in Glasgow, and the German meaning. The alliance, constitution, decorative movement, Bauhaus, cubism, futurism, style, Dada and so on, finally shaped the "aggregation" of modernism. So when the decorations of surrealism, Neo romanticism and other decorations come up again, modernism can still sit on the Diaoyutai, even in some special cases, some of its strengths are still reused, such as the fascist countries' use of mass production technology in military industry, and even during the great depression. The new industry chain brought by the professionalization. At that time, almost all progressive designers believed in the practical role of technological force in social upheaval. Gropius believed that the design of the plant was the correct expression of the specialization of workplaces in the building space. The Texaco gas station design of Walter Teague (Walter Darwin Teaque) is a "good style" that should be equipped with vehicle material and cultural artifacts. They have injected a completely realistic and thought-provoking look for modernism, but they also set a role model for designers to show how important this role is in our real life. In contrast, other design movements of the same period have restricted the development of the future because of the worship of classicism, or the obscuring of the streamlines of decoration. The radiant momentum of the new art movement is obviously not as easy and clear as the geometric abstraction of modernism, and the rich decorative vision also impedes the spread of democracy. It is the modernist who expresses the open mind of the machine and the future in the concise and hard form, and also symbolizes the longing and belief of the modern people in the new century in the new century.

\section{The history and present situation of modernism design}

Historians often find that Ludwig Mies Van der Rohe, designed by Ludwig Mies Van der Rohe, is a "textbook" modernist building in 1929, but the handmade Barcelona chair (Barcelona Chair) (Figure 1) is due to its expensive material and handicraft features. 


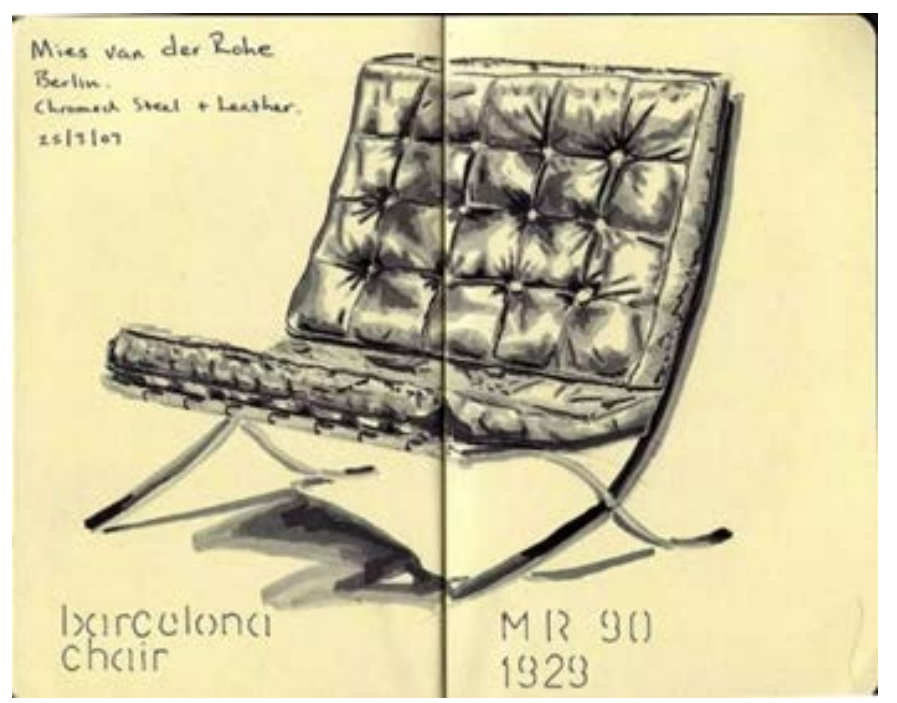

Figure 1 Barcelona Chair

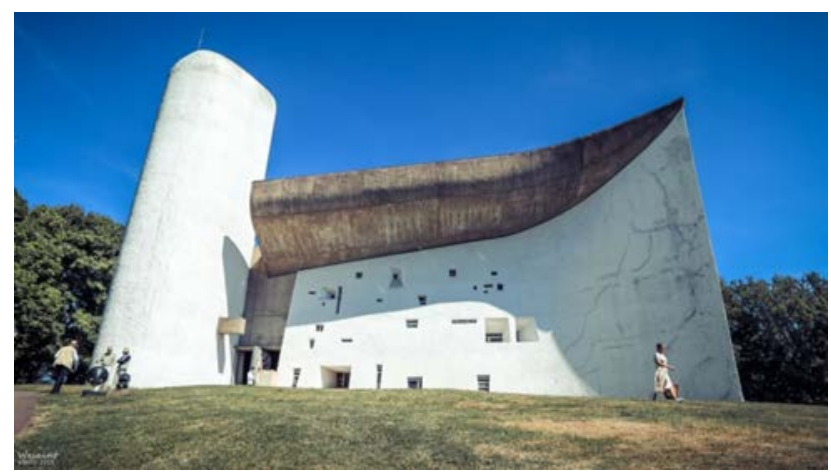

Figure 2 The Pilgrimage Chapel of Notre Dame du Hautat Ron-champ

And there is some irony in the perfect expression of Bauhaus's design concept. Although modernists think of the mission of shoulder to shoulder, most of their products are far from the taste and consumption of the masses. The education plan of the Bauhaus is also closed down by the Nazi blockade, and modernism has the opportunity to travel far and back. In contrast, the modernism on the other side of the ocean shows another kind of flexibility and adaptation, and the sincere cooperation with business, which makes American Modernism show a scientific and consummate image of mass consumption. They do not even exclude decoration and luxury. The curve curve of the European continent may be too enchanting and a compromise. The streamline is the right way here. However, the modern design, which seems to be "lively", is far from the mass life, which is a transition between the traditional wind and the vanguard modern. When Americans really realize that the pursuit of exquisite handwork is an era of illusion, Charles Ames (Charles Ray Eames) and the wonderful design of Eero Saarinen make mass production meet the aesthetic concept of modern design. At the same time, European modernists came one after another. They became the sharp weapon of the capital expansion of the American continent, and the international style came into being. But the other group of modernists who do not forget the original heart continue to work in the aesthetic point of view. Corbusier endows The Pilgrimage Chapel of Notre Dame Du Hautat Ron-champ (Figure 2) a "rough" style. The organic, sculptural and texture sense of the architecture is the original of the modernist to the nature and the truth. The aesthetic pursuit of points is basically similar to the aesthetic properties of Ames's plywood and plastic.

But in Europe after the modernists fled, modernism did not stop. Italy and the French took the customs and accents of the nation, actively integrated into the new pattern of modernism, and the 
great Paris plan made a modernist world. After the defeat, Germany also made efforts to restore Bauhaus's ideals through the establishment of the University of Ulm in Ulm. Rationalism has gradually become stylized and dogmatic in the two mainstream areas of modernism design in Europe and America, and has become "unified" through the introduction of world hegemony and monopoly capital, but also because of this style and dogma, it eventually becomes rigid and poor. Gradually evolved into a form of competition with historical style, popular culture and irrationalism. The theory of "Form Follows Function" and "Less is more" can no longer be the first principle of today's design practice. The accent of modernists becomes paradoxical. When modernist practice goes all the way, the absolutism of theory only reflects the design of modernism. A fantasy of reality, elitism and fashionable self narcissism, was attacked. The conflict between theory and ideal becomes irreconcilable, and the contradiction between theory and the real world is becoming increasingly prominent. Modernism, supported by the idea of progress, has lost its position in the face of the strong criticism of postmodernism. A design language returning to visual richness and cultural diversity is rising, and the popular, local and historic forms of intonation have been restored. But for today's designers and audience groups, the ideal of modernism is still precious, and the docking with the consumer market is the actual strategy of "grounding gas". Machine manufacturing and manual skills should co-exist in order to meet the needs of complex and changeable reality.

For a hundred years of modernism, we must see that, since the times of Behrens and Mutter and Hughes, the aesthetic connotation of mass production and mass production, and persistently endowed with the aesthetic connotation of adaptation to the times, has been achieved today, and today's popular products have been struggling with modernism. Blood. Whether it's Fukazawa Naohito (Nato Fukasama)'s small wall CD player (Figure 3) or the "Sponge Vase" of Marcel Wenders (Marcel Wanders), it's a proof of the continuity of the once modernist mother's offspring, and these charming, very luxurious products are no longer a workshop. Manual memory, but the result of integration on the assembly line. Therefore, all the modernist pioneers and the successors do, through a form of tangible works and works, stand in the frontiers of the times, heralding the spiritual change that the modern people are bound to experience, and the footsteps that are destined to advance after the progress of the society.

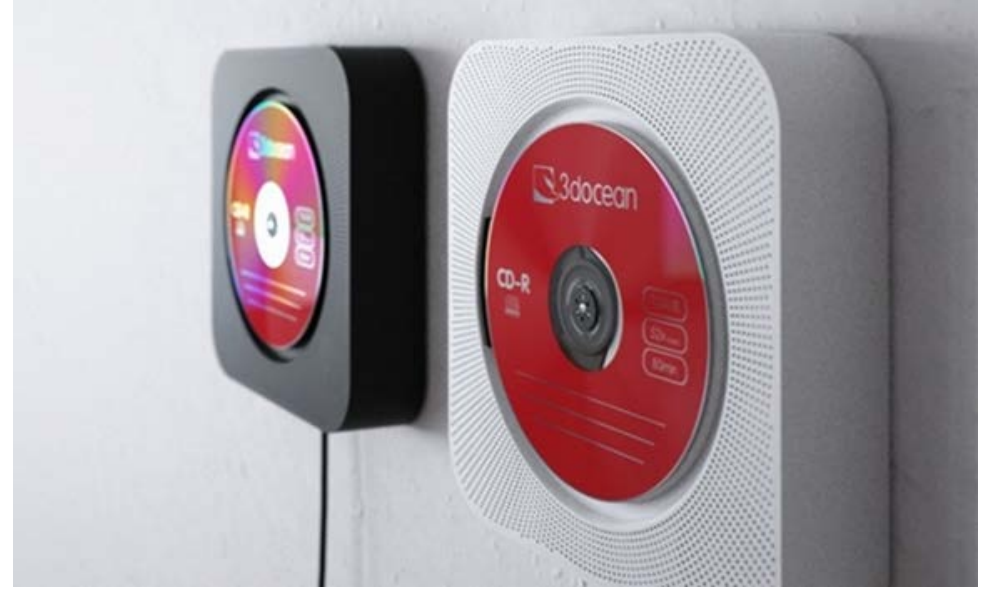

Figure 3 MUJI CD, Design by Nato Fukasama

\section{Modernist criticism}

Functional supremacy is not the only original intention of modernists. There is no necessary connection between simple form and indifference. Further, modern urban diseases such as urban 
congestion, air pollution, population explosion, and so on, are simply blamed on the modernist design, and will be extreme and have no help to solve the problem. At the same time, the arrival of "critical modernism" is worthy of our recognition and concern for the innovation and amendment of modernism itself. Today, the roaring of machines, the popularization of information and the leap of technology undoubtedly become an integral part of our life. In the era of Ruskin, evasion is only wishful thinking today. Whether fear or exclusion, the combination of reinforced concrete and curtain wall glass has been deeply rooted in the hearts of the people. The grid system in the plane, as a symbol, carries the ideal and pursuit of "peace and prosperity" from the Mondrian era, and melts into a social ideal in pursuit of a beautiful society and a happy life. Jencks's claim of "death" in modernism can only be a brief "dormancy". Because who can deny that modernist architecture has given private life a relatively private "home" rather than a "home farm" in the workshop era? Who can deny that today's rich and colorful design style is not based on the "unification of art and technology" pursued by modernism?

\section{Conclusion}

Today, the new modernist school, which continues to advance on the road of modernism, is more prudent and inclusive than ever. While reviewing the past, it is reasonable to draw on the ethical doctrines of modernism and to be careful to respond to the needs of the reality to make some kind of coordination, neither absoluteness nor risking. Modern life is rolling forward, modern design advances, absolute and relative will become history, if the macro views of this design process, the gain and loss of a hundred years' worth seeking. In twentieth Century, modernism was designed from vanguard avant-garde to later "home in the world" and became a symbol of modern life style. On the basis of the matching of "content and form", the creation of other design style should be derived, and the modernist style of design was finally chosen. Yi design is the most successful form of vocabulary in twentieth Century.

\section{References}

[1] (British) Nicholas Pevsner's "pioneers of modern design -- from William Maurice to Gropius", Wang Shenhu, China Architecture Industry Press, 1987.9

[2] (British) Reina banner: "theory and design of the first mechanical age", translated by Ding Lei and Zhang Xiaoying, Jiangsu Fine Arts Publishing House, 2009.11

[3] (British) Jonathan Woodham: Design in twentieth Century, Shanghai: Shanghai people's publishing house, 2012.8

[4] (British) Penny spark: introduction to design and culture, translated by Qian Fenggen and Yu Xiaohong, Nanjing: Yilin press, 2012.8

[5] (US) Robert Hughes's "shock of new art", translated by Liu Pingjun, Wang Jing and Zhang He, Shanghai people's fine arts publishing house, 1996.3

[6] (British) Peter Thomas: the meaning of modern design, translated by Zhang Bei, Nanjing: Yilin press, 2013.4

[7] (US) Stephen Bailey, Philip Garner: twentieth Century style and design, translated by Luo Yunyun, Chengdu: Sichuan people's publishing house, 2000.1 